\title{
Ancient Olfactory Schwannoma - Case Report and Literature Review
}

\author{
Mirko V. MICOVIC, Bojana M. ZIVKOVIC, Jelena D. ZIVANOVIC, Vladimir LJ. BASCAREVIC, \\ Vojislav BOGOSAVLJEVIC, Lukas G. RASULIC
}

Clinical Center of Serbia, Clinic of Neurosurgery, Belgrade, Serbia

\section{ABSTRACT}

Intracranial schwannomas are benign tumors that arise from Schwann cells. Since it is well known that optic and olfactory nerves do not have a Schwann cell sheath, schwannoma should not develop from these nerves.

We report a very unusual case of a 73-year-old female who presented with generalized seizures and had radiological features of an intracranial aneurysm. Additional imaging showed an extracerebral mass $2.5 \times 2.0 \mathrm{~cm}$ in size, which most likely corresponded to a meningioma. It was resected in total. Subsequent histological analysis revealed that the tumor was in fact ancient schwannoma WHO grade I.

Only about 41 case of olfactory schwannoma have been reported in the literature. Olfactory groove schwannomas are extremely rare tumors, occurring less frequently than any other intracranial nerve schwannoma. As in this case, the schwannoma should be included in the differential diagnosis of the anterior cranial fossa tumor. Further research on the pathogenesis and the origin of olfactory groove schwannoma is needed.

KEYWORDS: Intracranial tumors, Neurinoma, Olfactory dysfunction, Olfactory groove, Subfrontal approach

\section{INTRODUCTION}

I ntracranial schwannomas are benign tumors that arise from Schwann cells. Since it is well known that optic and olfactory nerves do not have a Schwann cell sheath, schwannoma should not develop from these nerves (17).

Schwannomas account for 8 - $10 \%$ of all intracranial tumors and occur mostly in patients between 20 and 50 years of age. Patients affected by schwannomas may be asymptomatic or present with various symptoms depending on the location, size and nerve of origin, and may include motor and sensory dysfunction, intracranial hypertension, headache and seizures (20).

These tumors present on Magnetic Resonance Imaging (MRI) as well-circumscribed, encapsulated masses, low-to intermediate signal intensity on T1-weighted images and high signal intensity on T2-weighted images. The signal intensity on T2-weighted images may be either homogeneously hyperintense or it can show a characteristic high signal intensity in the periphery and low signal intensity in the central region of the lesion. This $\mathrm{MR}$ imaging finding corresponds with pathologic findings to fibrous tissue (with high collagen content) centrally and more myxoid tissue peripherally (20).

Histopathologically, it consists of compact hypercellular Antoni A areas and myxoid hypocellular Antoni B areas. Cells are narrow, elongated and wavy with tapered ends interspersed with collagen fibers - spindle cells. Nuclear palisading around fibrillary processes (Verocay bodies) are often seen in cellular areas. Large irregularly spaced vessels, usually with thickened hyalinized walls and thrombi, are most prominent in Antoni $\mathrm{B}$ areas. Tumor cells have ill-defined cytoplasm, dense chromatin. It often displays degenerative nuclear atypia, but 
rare mitotic figures. There are no axons except where nerve is attached.

Immunohistochemical staining helps differentiating from other tumors that can present with similar histological characteristic -fibroblastic meningiomas, tanacytic ependymomas, subependymomas and pilocytic astrocytomas. Schwannomas contain Leu-7 and S-100 protein.

Different course of treatment for schwannomas include surgical excision, observation and radiotherapy (10).

\section{- CASE REPORT}

A 73-year-old female presented with the occasional generalized seizures over a two-year period and headaches over a twomonth period. Neurological examination on admission was entirely normal, revealing preserved olfaction and no other abnormality. There were no symptoms of increased intracranial pressure or a focal neurological deficit. No family history of Neurofibromatosis type I (Von Recklinghausen disease) was present.

A Computerized Tomography (CT) scan was performed which showed a hyperdense mass in the right subfrontal region. The initial diagnosis was an intracranial aneurysm, so the patient was admitted for further examination. A MRI scan with Magnetic Resonance Angiography was performed and showed an extracerebral mass $2.5 \times 2.0 \mathrm{~cm}$ in size, which most likely corresponded to an intracranial meningioma, with compression on both anterior cerebral arteries (ACA) and ischemia in the vascularization area of the right ACA. No evidence of extension into the ethmoid sinus was seen (Figure 1A-F).

The decision was made to proceed with the resection of the tumor.

A right subfrontal craniotomy was performed. After the initial exposure of the tumor, which was solid, adherent to the olfactory nerve, fibrous and calcified and surrounded by glial tissue, the tumor was totally resected. Because of tight adherence to the olfactory nerve, part of it was resected with the tumor (Figure 1A-F).

During histopathological analysis, on gross examination there were multiple, yellow to pearly white soft tissue pieces measuring $2.5 \times 2.0 \mathrm{~cm}$ altogether. Some of the soft tissue pieces showed areas of calcification. On microscopic examination, the tumor was hypocellular, although parts of it comprised of sweeping fascicles of slender elongated spindle cells with wavy serpentine nuclei and formation of Verocay bodies in some areas (Antoni A). These cells showed some pleomorphism and hyperchromatic nuclei, but mitotic figures were not evident. Occasional vessels displayed a periluminal hyaline ring. There were also areas of calcification. Immunohistochemical studies revealed that the tumor cells were positive for S-100 protein. The final diagnosis was schwannoma WHO grade I, with distinct degenerative changes, a so called "ancient schwannoma" (Figure 2A, B).
During the postoperative course, the patient did not have any seizures, but reported anosmia. Postoperative MRI confirmed total resection of the tumor. The patient was discharged on the 11 th day after surgery with anosmia and no seizures. On the follow-up examination after six months she regained olfaction.

The patient has consented to the submission of the case report for submission to the journal.

\section{DISCUSSION}

The most common origin of intracranial schwannomas is the vestibular branch of the eighth cranial nerve.

The PubMed database was searched online (PubMed, http:// pubmed.com). A search query using the terms olfactory schwannoma and subfrontal schwannoma in titles and/or abstracts revealed an additional 41 case (Table I). The mean age of the 41 patients, including our patient, was 31.85 years, which was significantly younger than our reported case. In addition, there were more males (65.85\%) than females, the male/female ratio being 1.93:1. A generalized seizure was found only in one other case.

This particular type of schwannoma was first reported in conjunction with central neurofibromatosis - Morbus Von Recklinghausen $(7,20)$, although there were no indications that our patient had this disease.

The origin of these lesions in the subfrontal region has always been enigmatic and many hypotheses have been put forth. The developmental theories suggest either transformation of mesenchymal pial cell into ectodermal Schwann cells or migration of the neural crest cells within the central nervous system (10). Also, dural branches of peripheral nerves which pass through the anterior cranial fossa may be nerves of origin for these tumors. Another theory suggests that reactive change after injury forms Schwann cells from multipotent mesenchymal cells (1).

Although literature shows that the majority of the reported cases were younger or middle aged males (Table I), our patient was elderly female, which makes this case even more interesting.

Histological type of the tumor in our case is above all fascinating. Because the tumor was discovered at late age, it can be concluded that it has been growing slowly, for a long period of time, and during its growth, many degenerative process took place, shaping our tumor into an ancient schwannoma. This histological type of schwannoma display pronounced degenerative changes in the form of cyst formation, calcification, hemorrhages and hyalinization. The tumor is usually infiltrated by a large number of foamy macrophages. Schwann cell nuclei can show atypical nuclei, which can be regarded as purely degenerative changes. The presence of hypercellularity and atypia my lead to the misdiagnosis of these lesions as sarcomas (melanomas, leiomyosarcomas, hemangiopericytomas). The absence of mitotic activity is the key feature to differentiate benign ancient schwannomas from malignant schwannomas. The presence of a capsule, evidence of prior hemorrhage, thick-walled 

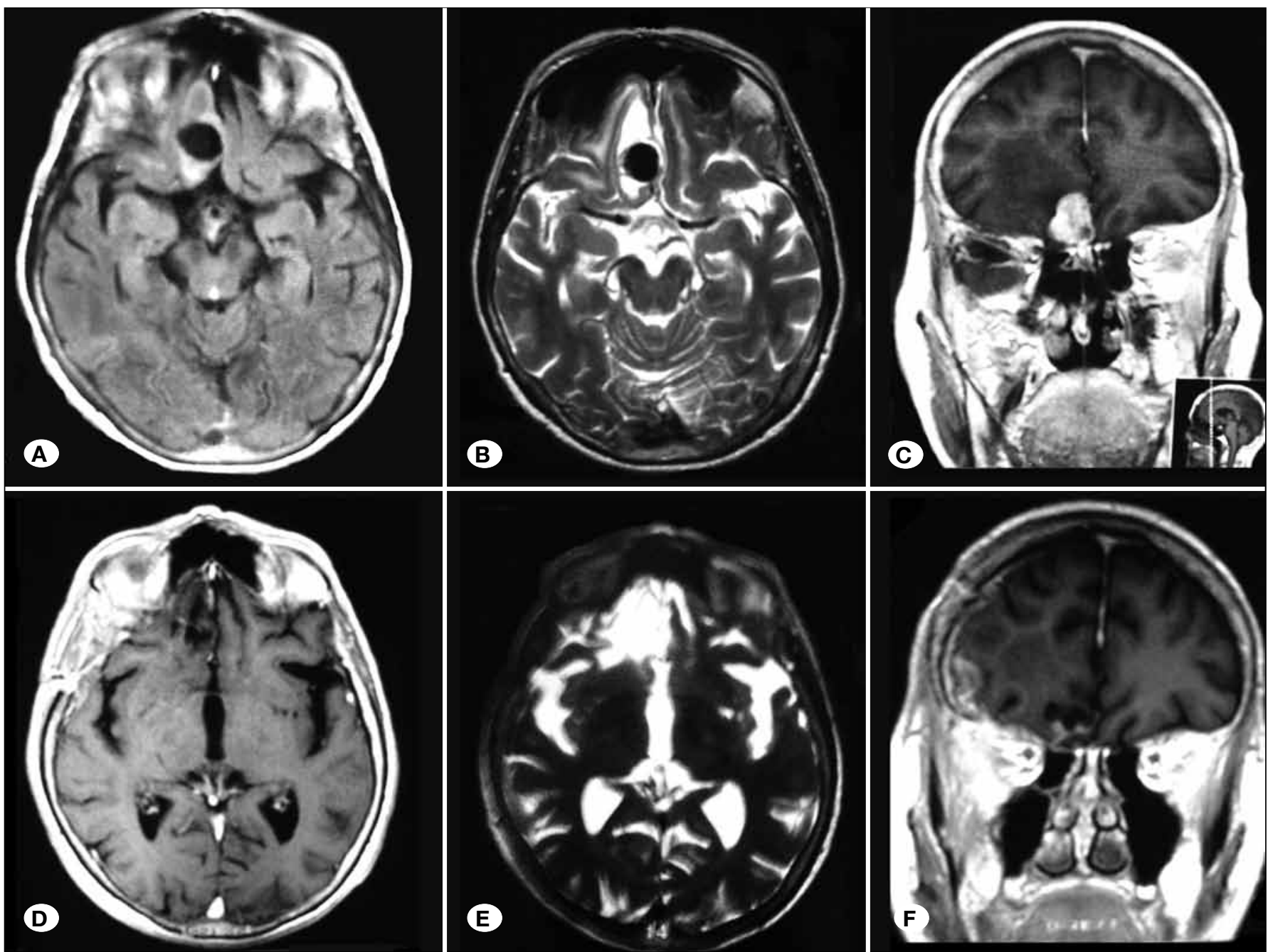

Figure 1: Magnetic Resonance Imaging (MRI) showing an extra-axial mass in the right frontal region near midline and elevating the olfactory bulb: A) Axial T1-weighted, B) axial T2-weighted and C) coronal T1-weighted preoperative MRI; D) Axial T1-weighted, E) axial T2-weighted and F) coronal T1-weighted postoperative MRI.
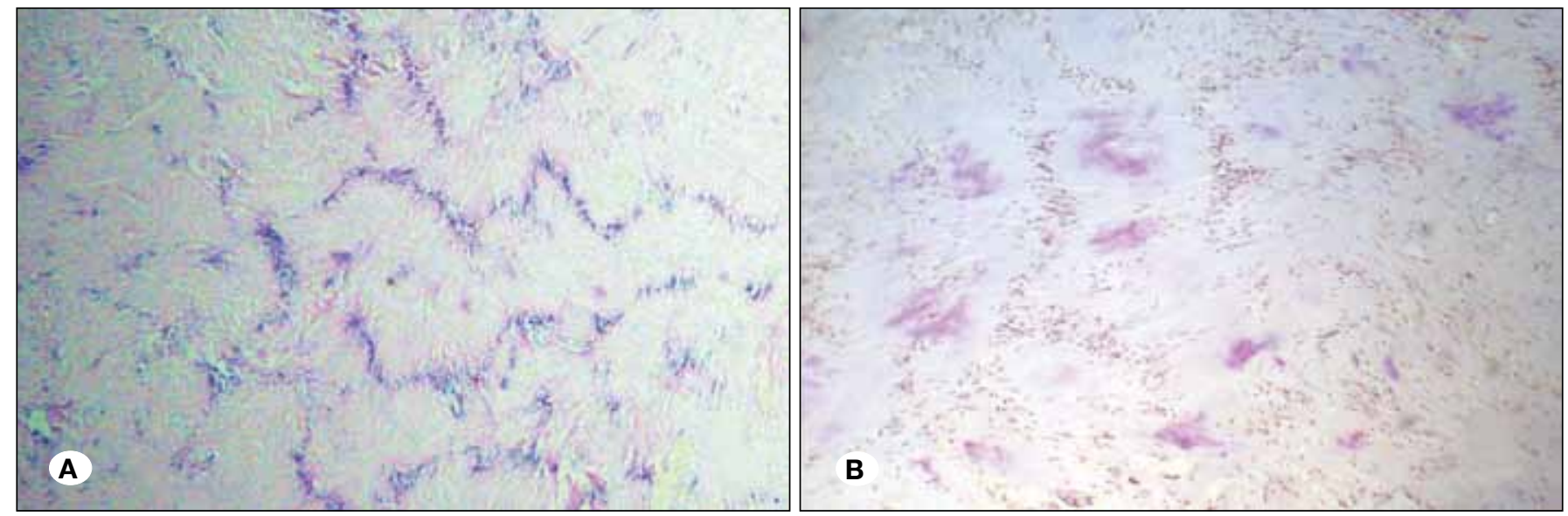

Figure 2: Microphotographs of the tumor: A) The tumor was hypocellular, although parts of it comprised of sweeping fascicles of slender elongated spindle cells with wavy serpentine nuclei and formation of Verocay bodies in some areas (Antoni A). These cells showed some pleomorphism and hyperchromatic nuclei, but mitotic figures were not evident. Occasional vessels displayed a periluminal hyaline ring. There were also areas of calcification; B) Immunohistochemical examination showed the tumor cells were positive for S-100 protein. 
Table I: Summary of 41 Cases of Olfactory Schwannoma Found in the Literature

\begin{tabular}{|c|c|c|c|c|c|c|c|}
\hline No. & Author & $\begin{array}{c}\text { Age } \\
\text { (years) }\end{array}$ & Gender & Clinical presentation & Anosmia & $\begin{array}{c}\text { Radiological } \\
\text { features }\end{array}$ & $\begin{array}{c}\text { Olfactory } \\
\text { tract }\end{array}$ \\
\hline 1 & Strum et al. (33) & 27 & M & Headache & Yes & / & Not seen \\
\hline 2 & Viale et al. (39) & 22 & M & Visual deficit & Yes & / & / \\
\hline 3 & Ulrich et al. (37) & 19 & M & Seizures, visual deficit & Yes & / & / \\
\hline 4 & $\begin{array}{l}\text { Vassilouthis and } \\
\text { Richardson (38) }\end{array}$ & 17 & $\mathrm{M}$ & Visual and cognitive deficit & Yes & Cystic, heterogeneous & / \\
\hline 5 & Mauro et al. (19) & 44 & $M$ & Visual and memory deficit & / & Cystic, heterogeneous & / \\
\hline 6 & Sato et al. (31) & 22 & $\mathrm{M}$ & Seizures & Yes & Solid, homogenous & Thinned \\
\hline 7 & Nagao et al. (23) & 63 & $\mathrm{~F}$ & Memory impairment & No & Cystic heterogeneous & / \\
\hline 8 & Husain et al. (14) & 55 & $\mathrm{~F}$ & Headache & Yes & / & / \\
\hline 9 & Harada et al. (12) & 33 & M & Headache & Yes & Solid, heterogeneous & Thinned \\
\hline 10 & Sabel and Teepen (28) & 17 & $\mathrm{M}$ & Seizures & / & Solid, homogeneous & / \\
\hline 11 & Huang et al. (13) & 33 & $M$ & Headache, visual deficit & No & Solid, homogeneous & / \\
\hline 12 & Boyd et al. (5) & 29 & $\mathrm{~F}$ & Seizures, headache & Yes & Cystic, heterogeneous & Involved \\
\hline 13 & Praharaj et al. (25) & 45 & $\mathrm{M}$ & Seizures, headache & / & Solid, homogeneous & Not seen \\
\hline 14 & Timothy et al. (35) & 33 & $\mathrm{~F}$ & Seizures & No & Solid, homogeneous & Not seen \\
\hline 15 & Gelabert et al. (11) & 19 & $\mathrm{M}$ & Seizures & No & Solid, homogeneous & / \\
\hline 16 & Tan et al. (34) & 21 & M & Seizures & No & Solid, homogeneous & / \\
\hline 17 & Tsai et al. (36) & 31 & $\mathrm{~F}$ & Seizures, headache & / & Solid, heterogeneous & / \\
\hline 18 & Yang et al. (41) & 55 & $\mathrm{M}$ & Headache & No & Solid, homogeneous & / \\
\hline 19 & Carron et al. (6) & 59 & $\mathrm{~F}$ & Headache, rhinorrhea & No & Solid, homogeneous & Involved \\
\hline 20 & Amador et al. (3) & 24 & $\mathrm{~F}$ & Hypoesthesia, visual deficit & / & Cystic, heterogeneous & Not seen \\
\hline 21 & de Souza et al. (9) & 27 & $\mathrm{M}$ & Headache & Yes & Cystic, homogeneous & / \\
\hline 22 & Prasad et al. (27) & 19 & $M$ & Seizures & Yes & Solid, heterogeneous & / \\
\hline 23 & Yuen et al. (42) & 33 & $\mathrm{~F}$ & Seizures & No & Solid homogeneous & Involved \\
\hline 25 & Murakami et al. (22) & 30 & $\mathrm{M}$ & Headache & No & Solid, homogeneous & Thinned \\
\hline 26 & Shenoy and Raja (32) & 55 & M & Seizures & No & Cystic, heterogeneous & Thinned \\
\hline 27 & Sano et al. (30) & 44 & $M$ & Seizures & No & Solid, heterogeneous & / \\
\hline 24 & Komoribayashi et al. (16) & 37 & $\mathrm{~F}$ & Seizures & Yes & Solid, homogeneous & Not seen \\
\hline 28 & Yako et al. (40) & 14 & $M$ & Headache & Yes & Solid, heterogeneous & Not seen \\
\hline 29 & Ahmad et al. (2) & 23 & $M$ & Seizures & No & Solid, heterogeneous & / \\
\hline 30 & Prak et al. (26) & 16 & $\mathrm{M}$ & Headache, diplopia & No & Solid, heterogeneous & Thinned \\
\hline 31 & Adachi et al. (1) & 22 & $\mathrm{~F}$ & Seizures & No & Solid, heterogeneous & Involved \\
\hline 32 & Saberi et al. (29) & 35 & $\mathrm{~F}$ & Seizures, headache, diplopia & Yes & Cystic, heterogeneous & / \\
\hline 33 & Daglioglu et al. (8) & 21 & M & Headache, aggressiveness & / & Cystic, heterogeneous & / \\
\hline 34 & Kanaan et al. (15) & 14 & M & $\begin{array}{l}\text { Headache, cognitive } \\
\text { impairment }\end{array}$ & Yes & Cystic, heterogeneous & / \\
\hline
\end{tabular}


Table I: Cont.

\begin{tabular}{llcclccc}
\hline No. Author & $\begin{array}{c}\text { Age } \\
\text { (years) }\end{array}$ & Gender Clinical presentation & Anosmia & $\begin{array}{c}\text { Radiological } \\
\text { features }\end{array}$ & $\begin{array}{c}\text { Olfactory } \\
\text { tract }\end{array}$ \\
\hline 35 & Bezircioglu et al. (4) & 33 & F & Headache & Yes & Solid, heterogeneous & / \\
\hline 36 & Mirone et al. (21) & 38 & M & Headache & Yes & Cystic, heterogeneous & / \\
\hline 37 & Choi et al. (7) & 39 & M & Headache & Yes & Cystic, heterogeneous Involved \\
\hline 38 & Figueiredo et al. (10) & 49 & M & Headache & Yes & Cystic, heterogeneous Thinned \\
\hline 39 & Lin et al. (18) & 32 & M & Seizures & / & Solid, heterogeneous \\
\hline 40 & Li et al. (17) & 16 & F & Seizures & No & Solid, heterogeneous \\
\hline 41 & Ogino-Nishimura et al. (24) & 41 & F & Headaches & Yes & Cystic, heterogeneous Involved \\
\hline
\end{tabular}

M: Male, F: Female.

vascular structures and areas representing degenerative changes also suggest a diagnosis of a benign lesion (21).

Treatment options for schwannomas include surgical excision, observation and radiotherapy, particularly Gamma knife therapy. Because the olfactory groove is an extremely rare location for these masses and is relatively difficult to biopsy, surgery is the optimal course of treatment. Complete removal of the tumor is necessary to prevent local recurrence.

\section{CONCLUSION}

Olfactory groove schwannomas are extremely rare tumors, occurring less frequently than any other intracranial nerve schwannoma. As in this case, the schwannoma should be included in the differential diagnosis of the anterior cranial fossa tumor. One of the objectives of this case report is to demonstrate that a benign tumor arising solely from the olfactory bulb can act as a primary epileptic focus and to illustrate the difficulty in making a preoperative diagnosis of pathological lesions in this area. Further research on the pathogenesis and the origin of olfactory groove schwannoma is needed. Complete removal is curative, but subtotal resection may be an acceptable option for the slow-growing nature of these tumors.

\section{REFERENCES}

1. Adachi K, Yoshida K, Miwa T, Ikeda E, Kawase T: Olfactory schwannoma. Acta Neurochir 149(6):605-610, 2007

2. Ahmad FU, Gupta A, Sharma MC, Shukla G, Mehta VS: The enigmatic origin of subfrontal schwannomas: Report of a case without hyposmia. Acta Neurochir 148(6):671-672, 2006

3. Amador AR, Santonja C, Del Pozo JM, Ortiz L: Olfactory Schwannoma 12(4):742-744, 2002

4. Bezircioglu H, Sucu HK, Rezanko T, Minoglu M: Nasalsubfrontal giant schwannoma. Turk Neurosurg 18(4):412-414, 2008

5. Boyd JH, Dalsaso TA Jr, Bee CS, Smith KR Jr, Martin DS: Subfrontal schwannoma with intracranial mucocele: A case report. Am J Otolaryngol 18:72-75, 1997
6. Carron JD, Singh RV, Karakla DW, Silverberg M: Solitary schwannoma of the olfactory groove: Case report and review of the literature. Skull Base 12(3):163-166, 2002

7. Choi YS, Sung KS, Song YJ, Kim HD: Olfactory schwannomacase report. J Korean Neurosurg Soc 45(2):103-106, 2009

8. Daglioglu E, Okay O, Dalgic A, Albayrak AL, Ergungor F: Cystic olfactory schwannoma of the anterior cranial base. $J$ Neurosurg 22(5):697-699, 2008

9. de Souza HL, Ramos AM, Ramos CC, Melo SP, Pereira HS, Madureira JF, de Lana JM: Olfactory groove schwannoma: Case report. Arq Neuropsiquiatr 61:125-128, 2003

10. Figueiredo EG, Gomes MQ, Soga Y, Amorim RL, Rosemberg $\mathrm{S}$, Teixeira MJ: A rare case of olfactory groove schwannoma. Arq Neuropsiquiatr 67(2B):534-535, 2009

11. Gelabert M, Fernandez J, Lopez E: Schwannoma of the olfactory groove. Neurologia 15:404-405, 2000

12. Harada T, Kawauchi M, Watanabe M, Kyoshima K, Kobayashi S: Subfrontal schwannoma - case report. Neurol Med Chir 32:957-960, 1992

13. Huang PP, Zagzag D, Benjamin V: Intracranial schwannoma presenting as a subfrontal tumor: Case report. Neurosurgery 40:194-197, 1997

14. Husain M, Mishra UK, Newton G, Husain N: Isolated olfactory groove neurilemmoma. Surg Neurol 37:115-117, 1992

15. Kanaan HA, Gardner PA, Yeaney G, Prevedello DM, Monaco EA 3rd, Murdoch G, Pollack IF, Kassam AB: Expanded endoscopic endonasal resection of an olfactory schwannoma. J Neurosurg Pediatr 2(4):261-265, 2008

16. Komoribayashi N, Arai $\mathrm{H}$, Kojo T, Obonai C, Wakabayashi J, Ogawa A: Subfrontal schwannoma: Case report. No Shinkei Geka 33:601-605, 2005

17. Li YP, Jiang S, Zhou PZ, Ni YB: Solitary olfactory schwannoma without olfactory dysfunction: A new case report and literature review. Neurol Sci 33(1):137-142, 2012

18. Lin SC, Chen MH, Lin CF, Ho DMT: Olfactory ensheathing cell tumor with neurofibroma like features: $A$ case report and review of the literature. J Neurooncol 97(1):117-122, 2010

19. Mauro A, Sciolla R, Sicuro L, Ponzio R: Solitary neurinoma of the anterior cranial fossa. J Neurosurg Sci 27:45-49, 1983 
20. McLendon R, Rosenblum M: Russell \& Rubinstein's Pathology of tumors of the nervous system, $5^{\text {th }}$ ed. Baltimore:Williams \& Wilkins, 1989

21. Mirone G, Natale M, Scuotto A, Rotondo M: Solitary olfactory groove schwannoma. J Clin Neurosci 16(3):454-456, 2009

22. Murakami M, Tsukahara T, Hatano T, Nakakuki T, Ogino E, Aoyama T: Olfactory groove schwannoma-case report. Neurol Med Chir 44(4):191-194, 2004

23. Nagao S, Aoki T, Kondo S, Gi H, Matsunaga M, Fujita Y: Subfrontal schwannoma: A case report. No Shinkei Geka 19:47-51, 1991

24. Ogino-Nishimura E, Nikagawa T, Mikami Y, Ito J: Olfactory ensheathing cell tumor arising from the olfactory mucosa. Case Report Med 2012:426853, 2012

25. Praharaj SS, Vajramani GV, Santosh V, Shankar SK, Kolluri S: Solitary olfactory groove schwannoma: Case report with review of the literature. Clin Neurol Neurosurg 101(1):26-28, 1999

26. Prak JH, Kim TY, Park JT, Kim JM: Olfactory grooving schwanoma: Case report. J Korean Neurosurg Soc 39:156158, 2006

27. Prasad D, Jalali R, Shet T: Intracranial subfrontal schwannoma treated with surgery and 3D conformal radiotherapy. Neurol India 52:248-250, 2004

28. Sabel LH, Teepen JL: The enigmatic origin of olfactory schwannoma. Clin Neurol Neurosurg 97(2):187-191, 1995

29. Saberi H, Khashayar P: Olfactory groove schwannoma masquerading as an orbital mass. Neurosciences 13(1):73-76, 2008

30. Sano H, Hayashi Y, Hasegawa M, Yamashita J: Subfrontal schwannoma without hyposmia-case report. Neurol Med Chir 44(11):591-594, 2004
31. Sato S, Toya S, Nakamura T, Ohtani M, Imanishi T, Kodaki K, Nakamura Y: Subfrontal schwannoma: Report of a case. No Shinkei Geka 13:883-887, 1985

32. Shenoy SN, Raja A: Cystic olfactory groove schwannoma. Neurol India 52(2):261-262, 2004

33. Strum KW, Bonis G, Kosmaoglou V: Uber ein neurinoma der lamina cribrosa. Zentrabl Neurochir 29:217-222, 1968 (In German)

34. Tan TC, Ho LC, Chiu HM, Leung SC: Subfrontal schwannoma masquerading as meningioma. Singapore Med J 42(6):275277,2001

35. Timothy J, Chakrabarty A, Rice A, Marks P: Olfactory groove schwannoma revisited. Acta Neurochir 141(6):671-672, 1999

36. Tsai YD, Lui CC, Eng HL, Liang CL, Chen HJ: Intracranial subfrontal schwannoma. Acta Neurochir 143:313-314, 2001

37. Ulrich J, Lévy A, Pfister C: Schwannoma of the olfactory groove. Case report and review of previous cases. Acta Neurochir 40(3-4):315-321, 1978

38. Vassilouthis J, Richardson AE: Subfrontal schwannoma. Report of a case. Acta Neurochir 53:259-266, 1980

39. Viale ES, Pau A, Turtas S: Olfactory groove neurinomas: Case report. J Neurosurg Sci 17:193-196, 1973

40. Yako K, Morita A, Ueki K, Kirino T: Subfrontal schwannoma. Acta Neurochir 147(6):655-657, 2005

41. Yang $\mathrm{SH}$, Song $\mathrm{SH}$, Kim SH, Kim Y: Olfactory grooving schwanoma: A case report. J Korean Neurosurg Soc 32:485487, 2002

42. Yuen A, Trost N, McKelvie P, Webster J, Murphy MJ: Subfrontal schwannoma: A case report and literature review. Clin Neurosci 11(6):663-665, 2004 